
КОМУНІКАТИВНО-КОГНІТИВНИЙ ПІДХІД ДО ФОРМУВАННЯ ТОЛЕРАНТНОЇ
МОВЛЕННЄВОЇ ПОВЕДІНКИ МАЙБУТНІХ УЧИТЕЛІВ ІНОЗЕМНОЇ МОВИ

\title{
COMMUNICATIVE AND COGNITIVE APPROACH TO FORM TOLERANT SPEECH BEHAVIOR OF FUTURE FOREIGN LANGUAGE TEACHERS
}

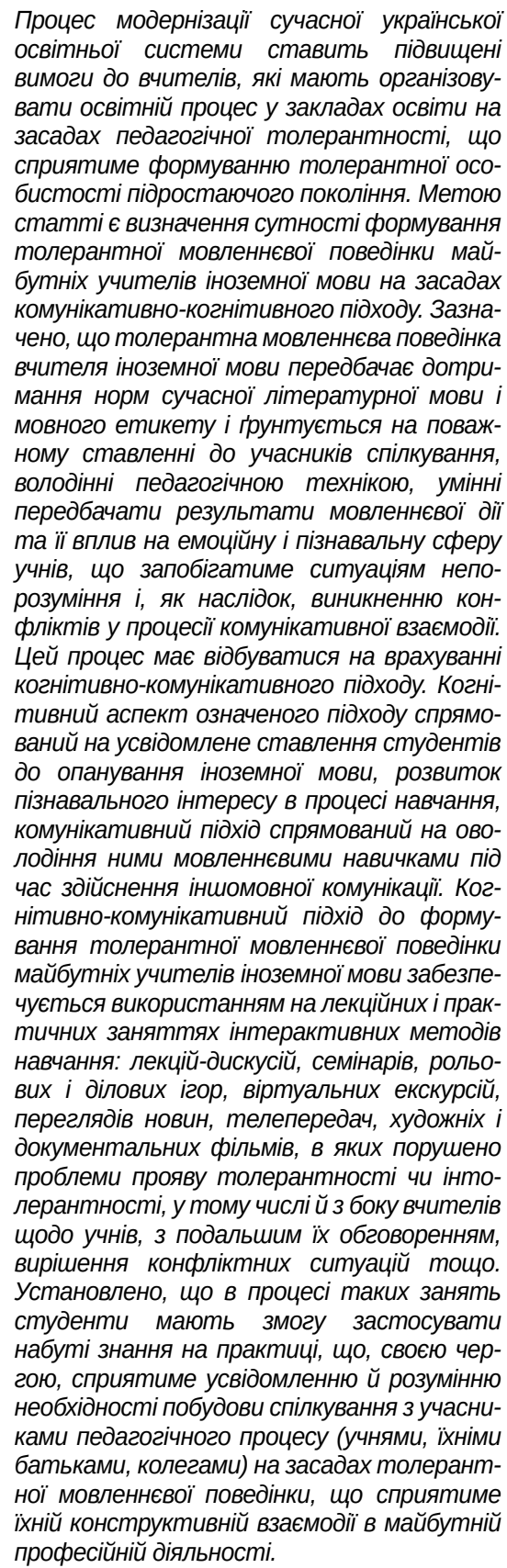

Процес модернізації сучасної української вати освіт засадах педагогічної толерантності, що сприятиме фрормуванню толерантної особистості підростаючого покоління. Метою формування комунікативно-когнітивного підходу. Зазначено, що толерантна мовленнєва поведінка вчителя іноземної мови передбачає дотри ному ставленні до учасників спілкування,

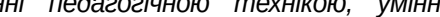
та ії вплив на емоційну і пізнавальну сореру учнів, що запобігатиме ситуаціям непорозуміння і, як наслідок, виникненню кон когнітивно-комунікативного підходу. Когніоси аспект оного підходу спрямодо опанування іноземної мови, розвиток пізнавального інтересу в прочесі навчання, комунікативний підхід спрямований на овочас здійснення іни нітивно-комунікативний підхід до формумолерантної мовленнєвої поведінки чується використанням на лекційних іпрактичних заняттях інтерактивних методів навчання: лекцій-дискусій, семінарів, рольо документальних фрільмів, в яких порушено проблеми прояву толерантності чи інтолерантності, у тому числі и з боку вчителів

УДК 378.147:808.2

DOI https://doi.org/10.32843/2663-60852019-17-1-22

\section{Логвіненко А.Ю.,}

канд. пед. наук

викладач кафедри германської фрілології та методики іноземних мов д3 «Південноукраїнський національний педагогічний університет імені К.Д. Ушинського»
Ключові слова: когнітивно-комунікативний підхід, толерантна мовленнєва поведінка, майбутні учителі іноземної мови, толерантність, професійна діяльність.

The process of modernization of the modern Ukrainian educational system places increased demands on teachers who have to organize the educational process in educational institutions on the basis of pedagogical tolerance, which will contribute to the formation of a tolerant personality of the younger generation. The purpose of the article is to determine the essence of the formation of tolerant speech behavior of future foreign language teachers on the basis of communicative and cognitive approach. It is noted that tolerant speech behavior of a foreign language teacher implies observance of the rules of modern literary language and linguistic etiquette, and is based on respectful attitude to the participants of communication, knowledge of pedagogical technique, ability to predict the results of speech action and and, as a consequence, conflicts in the process of communicative interaction. This process should take into account the cognitive and communicative approach. The cognitive aspect of this approach is directed at the conscious attitude of students to mastering a foreign language, the development of cognitive interest in the learning process, the communicative approach is aimed at mastering their speech skills during the implementation of foreign language communication. The cognitive and communicative approach to the formation of tolerant speech behavior of future foreign language teachers is ensured through the use of interactive teaching methods at lectures and seminars: lectures-discussions, seminars, role-playing and business games, virtual excursions, watching TV news, films, dealing with problems of tolerance or intolerance, with their further discussion, conflict resolution and so on. It is established that during such sessions students have the opportunity to apply the acquired knowledge in practice, which, in turn, will promote awareness and understanding of the need to build communication with the participants of the pedagogical process (students, their parents, colleagues) on the basis of tolerant speech behavior, their daily behavior constructive interaction in future professional activity. Key words: communicative and cognitive approach, tolerant speech behavior, future foreign language teachers, tolerance, professional activity.
Постановка проблеми у загальному вигляді. Процес модернізації сучасної української освітньої системи ставить підвищені вимоги до вчителів, які мають організовувати освітній процес у закладах освіти на засадах педагогічної толерантності, що сприятиме формуванню толерантної особистості підростаючого покоління. Це зумовлено тим, що нині, на жаль, у суспільстві спостерігаються частіше прояви інтолерантності у ставленні не лише до представників інших культур і релігій, а й до співвіт- чизників, що зумовлено економічною, соціальною і політичною нестабільністю в Україні. Формування толерантності має розпочинатися зі шкільного віку, а отже, на вчителів покладено завдання навчити учнів вміти налагоджувати взаємовідносини з довколишніми людьми в досить складному і суперечливому світі. Значну роль у цьому процесі відіграють вчителі іноземної мови, оскільки саме вони $€$ носіями не тільки української культури, а й знайомлять школярів з особливостями різноманітних культур. 
Варто зазначити, що нині в закладах середньої освіти взаємовідносини не тільки між учнями, а й між учнями і вчителями дедалі більше набувають характеру інтолерантності. Це викликає значне занепокоєння, оскільки саме поведінка вчителя, у тому числі й мовленнєва, є взірцем для наслідування підростаючого покоління. Як зазначає Ю. Гордієнко, вчителі нині подекуди агресивно поводяться щодо своїх вихованців, дозволяючи собі виявляти ворожість, роздратування, насмішки, фрізичний вплив на учнів або довколишні предмети, вербальні образи, крик, погрози, відмову виконувати свої обов'язки, необґрунтовану вимогливість, застосування покарань, авторитарність, демонстрацію своєї сили та статусної переваги над дітьми, антипатію до окремих школярів, зневагу [5, с. 16].

3 огляду на це на заклади вищої педагогічної освіти покладено важливе завдання формування педагогічної толерантності в майбутніх учителів іноземної мови під час навчання, що, своєю чергою, вимагає принципової перебудови процесу підготовки майбутніх учителів іноземних мов на засадах толерантності, спрямованого на набуття ними не лише професійних знань, а й формування морально-духовних цінностей, толерантного ставлення до людини незалежно від раси, національності, віросповідання, соціального стану чи місця проживання, готових до конструктивної толерантної взаємодії і взаєморозуміння з усіма учасниками педагогічного процесу [7, с. 19].

Аналіз останніх досліджень і публікацій. Слід зазначити, що проблема толерантності дедалі більше привертає увагу науковців у різних аспектах. Так, із позиції фрілософрії ії розглядали А. Акулова, В. Андрущенко, Б. Джиліан, О. Довгополова, В. Золотухін, І. Зязюн, В. Кремень, В. Лекторський, В. Шинкарук та ін., в аспекті психології Б. Ананьєв, О. Асмолов, О. Бабчук, Г. Безюлєва, В. Бойко, І. Бех, С. Бондирєва, А. Коєн, Г. Олпорт, В. Павленко, В. Семиченко, Г. Солдатова, О. Шаюк та ін., з педагогічного погляду - О. Біда, В. Бондар, Т. Бузовська, Т. Варенко, С. Грант, О. Зарівна, Л. Кондрашова, М. Кренстон, П. Ніколсон, О. Сміт, О. Столяренко, В. Сухомлинський, Д. Сью, Н. Ткачова, Ю. Тодорцева, О. Шавріна та ін. Дослідники акцентують на суперечливості означеного френомена, неоднозначності сприйняття його учнями в практиці виховання толерантної особистості, презентують різноманітні засоби її формування.

Виділення невирішених раніше частин загальної проблеми. Натомість проблему фрормування толерантної мовленнєвої поведінки в майбутніх учителів іноземної мови в науковій психолого-педагогічній літературі висвітлено недостатньо. Виникає нагальна необхідність забезпечення навчально-методичного супроводу підготовки майбутніх учителів іноземної мови на принципах толерантної мовленнєвої поведінки у процесі їхнього навчання в закладах вищої педагогічної освіти.

Мета статті полягає у визначенні сутності фрормування толерантної мовленнєвої поведінки майбутніх учителів іноземної мови на засадах комунікативно-когнітивного підходу.

Виклад основного матеріалу. Зауважимо, що вперше глобально проблему толерантності було порушено 16 листопада 1995 р. на Генеральній конференції ЮНЕСКО, на якій було прийнято Декларацію принципів толерантності, в якій толерантність трактується як повага, прийняття й адекватне розуміння розмаїття культур світу, форм самовираження і способів вияву людської індивідуальності.

Варто зазначити, що дослідниками сутність толерантності розглядається по-різному. Наприклад, Є. Столяренко визначає її так: 1) терпимість, поблажливість до когось чи чогось; 2) терпимість однієї людини до іншої, незважаючи на розрізнені погляди, смаки, вчинки, стилю поведінки, способу життя тощо; визнання особою права на існування в іншого суб'єкта власних переконань, поглядів, які відрізняються від її власних об'єктів переваг; внутрішня усвідомлена терпимість особистості, що ґрунтується на моральній емпатії; 3) терпимість, витривалість, психічна сталість за наявністю фррустраторів і стресорів; терпимість до різних поглядів, неупередженість щодо оцінювання людей і подій; 4) утримання від протесту чи будь-якої реакції засудження при збереженні себе як морального суб'єкта й небайдужого ставлення до світу [9, с. 233].

На думку О. Третьякової, толерантність - це духовно-моральна якість особистості, що виражена в прийнятті «іншого» як особистості, незалежно від національності, мови, віросповідання, переконань, належності до громадських організацій, соціального, майнового і службового станів (соціальні і культурні характеристики), а також віку, стану здоров'я, статі, раси (антропологічні характеристики) [10, с. 8].

Не можна не погодитися з Н. Асташовою, яка зазначає, що толерантній особистості, у тому числі й учителя іноземної мови, мають бути притаманні такі основні психолого-етнічні та соціальні характеристики, як гуманність (безмежна віра в силу добра в міжособистісних стосунках і в самоцінність внутрішнього світу людини, який не передбачає жодного насилля), рефлексивність (як здатність осмислювати особистісні відносини, розуміючи їх плюси та мінуси, співвідносити їх із толерантним світосприйняттям), мобільність (здатність коригувати систему відносин залежно від умов та обставин), упевненість у собі й у своїх силах, самовладання, варіативність у підході до довколишньої дійсності, здатність правильно оці- 
нити ситуацію та прийняти потрібне рішення, відповідальність за прийняття рішень та їх реалізацію, перцепція (уміння спостерігати за людьми), емпатія (здатність ставити себе на місце іншої людини, розуміти її вчинки й спосіб мислення, вміння порівнювати свою поведінку зі станом іншої людини, почуття гумору) [2, с. 77-78].

Розглядаючи проблему підготовки майбутніх учителів іноземної мови до фрормування толерантності в учнів основної школи, ми дійшли висновку, що їхня підготовленість до означеної діяльності $€$ інтегративною властивістю особистості, що характеризується ціннісним ставленням до людей незалежно від їхньої національної, культурної, релігійної, вікової, статевої, соціальної приналежності, повагою до думок інших, звичаїв, вірувань, інтересів та почуттів, прийняттям ідей толерантності як загальнолюдської, особистісної і професійної цінності, здатністю до організації толерантної взаємодії у процесі навчання іноземних мов як на уроці, так і в позакласний час, уміннями конструктивного вирішення конфліктних ситуацій засобами діалогових стратегій [7, с. 45].

Натомість для того, щоб виховувати толерантність у учнів, необхідно навчити самих студентів дотримуватися толерантної мовленнєвої поведінки в процесі комунікації з учасниками педагогічного процесу. Толерантна мовленнєва поведінка вчителя іноземної мови передбачає дотримання норм сучасної літературної мови і мовного етикету і ґрунтується на поважному ставленні до учасників спілкування, володінні педагогічною технікою, умінні передбачати результати мовленнєвої дії та ії вплив на емоційну і пізнавальну сореру учнів, що запобігатиме ситуаціям непорозуміння i, як наслідок, виникненню конфліктів у процесії комунікативної взаємодії.

На нашу думку, цей процес має відбуватися 3 урахуванням когнітивно-комунікативного підходу. Когнітивний аспект означеного підходу спрямований на усвідомлене ставлення студентів до опанування іноземної мови як передумови успішної професійної діяльності в подальшому, розвиток пізнавального інтересу в процесі навчання, а комунікативний підхід спрямований на оволодіння ними мовленнєвими навичками під час здійснення іншомовної комунікації.

За О. Черпак, когнітивний підхід передбачає усвідомлене засвоєння студентами культурнокраїнознавчих відомостей та мовного матеріалу. Комунікативний компонент розглядається через технології навчання, що забезпечують інтерактивне, особистісно-мотиваційне спілкування студентів на заняттях 3 іноземної мови. 3 огляду на зазначене, саме когнітивно-комунікативний підхід у вивченні іноземних мов дає змогу найповніше реалізувати освітньо-виховний потенціал предмета [11].
Когнітивний підхід, за визначенням І. Колеснікової, - це теорія навчання іноземних мов, що розроблена на підставі когнітивної психології. Щодо навчання іноземної мови когнітивізм означає, що вивчення певного лінгвістичного явища має спиратися на розумові процеси і дії, що лежать в основі розуміння і використання цього явища в мовленні [6, с. 198].

Когнітивний підхід розглядається також як свідомий пізнавальний підхід, що спрямовує діяльність студентів на засвоєння правил, використання лексико-граматичних моделей, на основі яких здійснюється свідоме конструювання висловлювань. У когнітивній моделі навчання необхідно, щоб студенти були активними й свідомими учасниками у процесі засвоєння мовних навичок та їх практичному застосуванні [8].

І. Колесніковою виокремлюються такі рівні когнітивності: рівень правила (виконання мовленнєвих дій згідно з правилом); рівень значення (усвідомлення і розуміння значення лексичних одиниць, що вивчаються); рівень виконання мовленнєвої діяльності (яким чином будується висловлювання, з чого починається, чим закінчується, які аргументи наводяться); соціальний рівень (усвідомлення фрункції висловлювання (прохання, порада, заперечення тощо); культурологічний рівень (усвідомлення того, наскільки інфрормація, що повідомляється, відповідає культурним нормам носіїв мов); когнітивний стиль роботи студентів (усвідомлення студентом того, як він/вона навчається, які прийоми використовує, оцінка їх ефрективності, а також самооцінка рівня володіння мови [6, с. 198].

щодо комунікативного підходу до вивчення іноземної мови, то він зорієнтований, насамперед, на спілкування. Реалізація цього підходу в освітньому процесі з іноземної мови означає, що фрормування іншомовних мовленнєвих навичок і вмінь відбувається шляхом і завдяки здійсненню іншомовної мовленнєвої діяльності. Інакше кажучи, оволодіння фронетичними, лексичними, граматичними засобами спілкування забезпечується їх практичним застосуванням у процесі спілкування на заняттях з іноземної мови. Вважаємо, що оволодіння майбутніми учителями іноземної мови уміннями говоріння, аудіювання, читання і письма найбільш ефрективно буде відбуватися під час реалізації зазначених видів мовленнєвої діяльності в умовах ситуативного навчання, що моделюють ситуації реального спілкування. У зв'язку з цим навчальна діяльність студентів має організовуватись у такий спосіб, щоб вони виконували вмотивовані дії з мовленнєвим матеріалом для вирішення комунікативних завдань, спрямованих на досягнення цілей та намірів спілкування.

За Л. Голованчук, формування комунікативної компетентності, що, на нашу думку, передбачає й толерантну мовленнєву поведінку майбутніх учи- 
телів іноземної мови, неможливе без оволодіння ними певним обсягом культурної інфрормації, без ознайомлення 3 культурою народу, мову якого вивчають. Тому одним із складників означеної компетентності автором виокремлено соціокультурну компетенцію, що сприяє розумінню спільного й відмінного між культурами, формуванню толерантності, допомагає здійснювати міжкультурні обміни та діяти свідомо й відповідально, забезпечує фрормування цінностей і норм поведінки (інтерес до інших, здатність до проникнення та симпатії, сміливість у висловлюванні власної думки, готовність брати на себе відповідальність, здатність до співпраці).

Носії мови, за твердженням науковця, з розумінням ставляться до мовних помилок, проте негативно реагують на незнання культури комунікативної поведінки та етикету, характерного для їхнього мовного середовища. Тому незнання культури, традицій іншого народу можуть призвести до непорозумінь чи виникнення проблемних ситуацій у спілкуванні. Для уникнення такого явища, як «культурний шок», необхідним $€$ формування в майбутніх учителів іноземної мови соціокультурної компетенції, «яка передбачає здатність взаємодіяти, спілкуватися у міжкультурному контексті; вона визначається як здатність адекватно і гнучко поводитись у ситуаціях зіткнення з діями, позиціями та очікуваннями представників інших культур» [4, с. 29-30].

Вважаємо, що когнітивно-комунікативний підхід до фрормування толерантної мовленнєвої поведінки майбутніх учителів іноземної мови забезпечує фрормування в них мовної, мовленнєвої, соціокультурної, країнознавчої та лінгвокраїнознавчої компетенцій.

Розглядаючи сутність означених компетенцій, Л. Барановська зазначає, що мовна компетенція це знання засобів мови, одиниць і категорій усіх рівнів, а також правила, за якими будують мовні конструкції та вміння застосовувати ці правила. Мовна компетенція становить собою сукупність мовних знань (лексичних, фонетичних, орфографрічних і граматичних) та умінь і навичок їх продуктивного використання.

Мовленнєва компетенція - це сорормованість умінь активного оперування чотирма видами мовленнєвої діяльності: говоріння, аудіювання, читання, письмо; це здатність усвідомлювати, сприймати та розуміти висловлювання.

Соціокультурну компетенцію доречно формувати з урахуванням її країнознавчого, лінгвокраїнознавчого та соціолінгвістичного складників.

Країнознавча компетенція передбачає володіння майбутніми вчителями іноземної мови знаннями про культуру країни, мова якої вивчається (знання географії, історії, економіки, державного устрою, особливостей побуту, традицій та звичаїв).
Лінгвокраїнознавча компетенція передбачає сорормованість у студентів цілісної системи знань про культуру країни, мова якої вивчається (література, живопис, архітектура, музика), та будову мови, її систему, особливості, схожість та відмінність із рідною мовою [3, с. 22-23].

На нашу думку, когнітивно-комунікативний підхід до фрормування толерантної мовленнєвої поведінки майбутніх учителів іноземної мови у своїй основі забезпечується використанням на лекційних і практичних заняттях інтерактивних методів навчання: лекцій-дискусій, семінарів, рольових і ділових ігор, віртуальних екскурсій, переглядів новин, телепередач, художніх і документальних фрільмів, в яких порушено проблеми прояву толерантності чи інтолерантності, у тому числі й з боку вчителів щодо учнів, з подальшим їх обговоренням, вирішення конфрліктних ситуацій тощо. Саме під час проведення таких занять студенти мають можливість застосування набутих знань на практиці, що, своєю чергою, сприятиме усвідомленню й розумінню необхідності побудови спілкування з учасниками педагогічного процесу (учнями, їхніми батьками, колегами) на засадах толерантної мовленнєвої поведінки, що сприятиме їхній конструктивній взаємодії у майбутній професійній діяльності.

Висновки. Підсумовуючи, доходимо висновку, що когнітивно-комунікативний підхід до вивчення іноземної мови сприяє не лише набуттю майбутніми вчителями необхідних професійних знань, а й забезпечує розвиток практичних умінь і навичок їх застосування в різноманітних навчальних ситуаціях, що передбачають побудову конструктивної взаємодії між їх учасниками на підставі толерантної мовленнєвої поведінки.

Перспективу подальших наукових розвідок вбачаємо в розробленні методики формування толерантної мовленнєвої поведінки майбутніх учителів іноземної мови на заняттях із фахових і психологопедагогічних навчальних дисциплін.

\section{БІБЛІОГРАФІЧНИЙ СПИСОК:}

1. Активізація комунікативного підходу на уроках англійської мови (з досвіду роботи). URL: http://school3loz.clan.su/_ld/0/10_Kaschejeva.pdf.

2. Асташова Н.А. Проблема воспитания толерантности в системе образовательных учреждений. Толерантное сознание и формирование толерантных отношений (теория и практика) : сборник научно-методических статей. Москва : Московский психолого-педагогический институт; Воронеж : Модэк, 2002. С. 74-83.

3. Барановська Л.В. Комунікативний та компетентнісний аспекти підготовки фрілологів до майбутньої професійної діяльності. Наукова школа академіка I.A. Зязюна у його соратниках та учнях : матеріали 2-ї міжн. конф. Харків : ХПІ, 2016. C. 21-25.

4. Голованчук Л.П. Навчання учнів основної загальноосвітньої школи культурно-країнознавчої 
компетенції на уроках англійської мови : автореср. дис. ... канд. пед. наук : 13.00.02. Київ, 2003. 20 с.

5. Гордієнко Ю.А. Формування педагогічної толерантності майбутніх учителів іноземних мов початкової школи : дис. ... канд. пед. наук : 13.00.04. Луцьк, 2017. 341 с.

6. Колесникова И., Долгина О. Англо-русский терминологический справочник по методике преподавания иностранных языков. СанктПетербург : Рус.-Балт. информ. центр БлИЦ, 2008. 223 c.

7. Логвіненко А.Ю. Підготовка майбутніх учителів іноземної мови до фрормування толерантності учнів основної школи : дис. ... канд. пед. наук : 13.00.04. Одеса, 2017. 293 с.
8. Методика викладання іноземних мов у середніх навчальних закладах: Підручник. Вид. 2-е, випр. і перероб. / Кол. авторів під керівн. С.Ю. Ніколаєвої. Київ : Ленвіт, 2002. 328 с.

9. Столяренко О.В. Виховання культури толерантних взаємин у студентської молоді : навчальнометодичний посібник. Вінниця : ТОВ «Нілан-ЛТД», 2014. $248 \mathrm{c}$.

10. Третьякова Е.Н. Толерантность как духовнонравственное качество личности : автореф. дис. ... канд. фрилософр. наук : 09.0013. Санкт-Петербург, 2011. 25 c.

11. Черпак О. Когнітивно-комунікативний метод навчання іноземної мови у BH3. URL: http://eur-lex. europa.eu; http://confesp.fl.kpi.ua/fr/node/994. 